Utah State University

DigitalCommons@USU

$5-1992$

\title{
Effect of Various Growth-Promoting Factors on Preimplantation Bovine Embryo Development in Vitro
}

Mark Randall Flood

Utah State Universitty

Follow this and additional works at: https://digitalcommons.usu.edu/etd

Part of the Animal Sciences Commons

\section{Recommended Citation}

Flood, Mark Randall, "Effect of Various Growth-Promoting Factors on Preimplantation Bovine Embryo Development in Vitro" (1992). All Graduate Theses and Dissertations. 4044.

https://digitalcommons.usu.edu/etd/4044

This Dissertation is brought to you for free and open access by the Graduate Studies at DigitalCommons@USU. It has been accepted for inclusion in All Graduate Theses and Dissertations by an authorized administrator of DigitalCommons@USU. For more information, please contact digitalcommons@usu.edu.

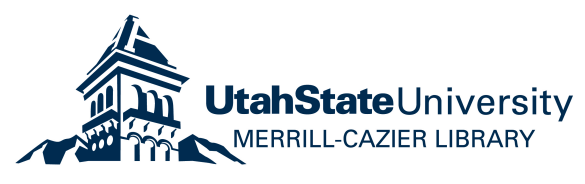




\section{EFFECT OF VARIOUS GROWTH-PROMOTING FACTORS ON PREIMPLANTATION BOVINE EMBRYO DEVELOPMENT IN VITRO}

by

Mark Randall Flood

A dissertation submitted in partial fulfillment of the requirements for the degree

of

DOCTOR OF PHILOSOPHY

in

Animal Science

(Embryology)

Approved :

UTAH STATE UNIVERSITY

Logan, Utah 


\section{ACKNOWLEDGEMENTS}

I would like to thank Dr. Thomas D. Bunch for his guidance and support of this research. Special thanks goes to Dr. Rex Spendlove and Dale Kern of HyClone Laboratories for their financial and moral support of my research.

I would also like to thank my other committee members, Dr. Dave Marcinkowski, Dr. Kenneth White, and Dr. LeGrande Ellis, for their patience and encouragement. Other former committee members who need to be recognized include the late Dr. "Betty" Boeker, Dr. Jay Call and Dr. Scott Woodward.

Special appreciation goes to everyone at the Physiology Lab, including Cole Evans, Lyle Henroid, Dan Durney, and Dr. Shiquan Wang, for dealing with me daily. Extra special appreciation is extended to Alma Maciulis for her professionalism and friendship throughout my stay at Utah state. I will truly miss our friendship when I finally leave. Also, thanks goes to Tami Gage for her assistance in carrying out this project.

I would like to thank my mother and father, Melvin and Linda Flood, and my mother- and father-in-law, Jean and Roger Been, for their emotional support during my stay here in Utah.

Last but not least, I want to extend my deepest gratitude to my wife, Lori, and my daughter, Amanda, for their patience, understanding, sacrifice, and undying devotion in support of my research and professional endeavors.

Mark Randall Flood 
ACKNOWLEDGEMENTS $\ldots \ldots \ldots \ldots \ldots \ldots \ldots \ldots \ldots \ldots \ldots \ldots \ldots \ldots \ldots \ldots$

LIST OF TABLES $\ldots \ldots \ldots \ldots \ldots \ldots \ldots \ldots \ldots \ldots \ldots \ldots \ldots \ldots \ldots \ldots \ldots \ldots$

LIST OF FIGURES $\ldots \ldots \ldots \ldots \ldots \ldots \ldots \ldots \ldots \ldots \ldots \ldots \ldots \ldots \ldots$

ABSTRACT $\ldots \ldots \ldots \ldots \ldots \ldots \ldots \ldots \ldots \ldots \ldots \ldots \ldots \ldots \ldots \ldots \ldots \ldots \ldots \ldots \ldots$

INTRODUCTION $\ldots \ldots \ldots \ldots \ldots \ldots \ldots \ldots \ldots \ldots \ldots \ldots \ldots \ldots \ldots \ldots \ldots \ldots \ldots$

OBJECTIVES $\ldots \ldots \ldots \ldots \ldots \ldots \ldots \ldots \ldots \ldots \ldots \ldots \ldots \ldots \ldots \ldots \ldots \ldots \ldots \ldots$

REVIEW OF LITERATURE $\ldots \ldots \ldots \ldots \ldots \ldots \ldots \ldots \ldots \ldots \ldots \ldots \ldots \ldots$

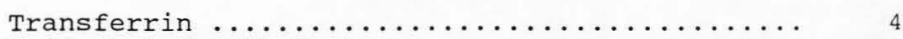

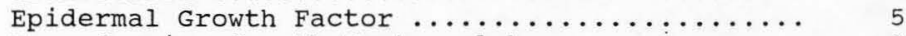

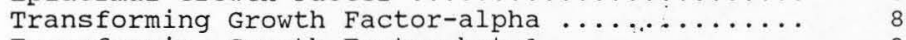

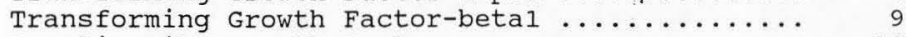

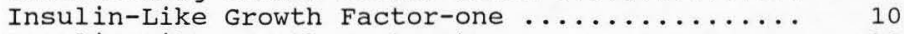

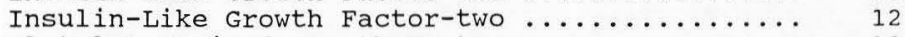

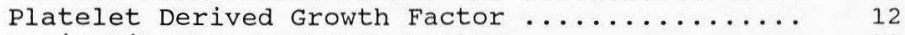

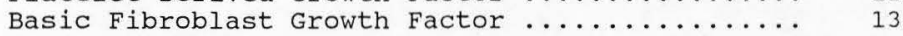

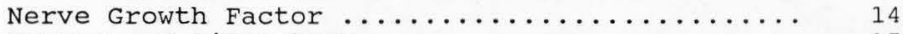

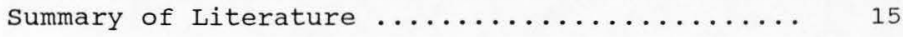

MATERIALS AND METHODS $\ldots \ldots \ldots \ldots \ldots \ldots \ldots \ldots \ldots \ldots \ldots \ldots \ldots$

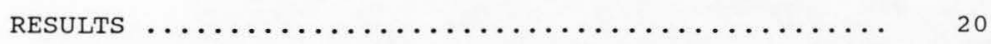

DISCUSSION $\ldots \ldots \ldots \ldots \ldots \ldots \ldots \ldots \ldots \ldots \ldots \ldots \ldots \ldots \ldots \ldots \ldots \ldots \ldots \ldots \ldots$

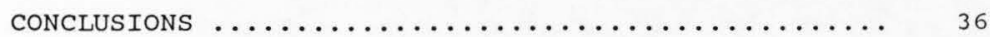

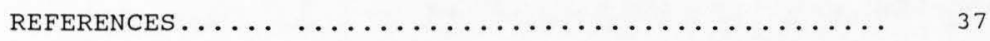

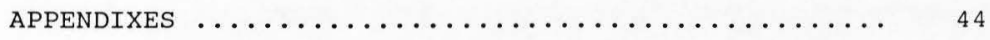

Appendix I. Formulation for Fert-TALP ....... 45

Appendix II. Formulation for sp-TALP .......... 45

Appendix III. Formulation for Control Medium .. 46

Appendix IV. List of Abbreviations ........ 47

VITA $\ldots \ldots \ldots \ldots \ldots \ldots \ldots \ldots \ldots \ldots \ldots \ldots \ldots \ldots \ldots \ldots \ldots \ldots \ldots \ldots \ldots \ldots$ 


\section{LIST OF TABLES}

\section{Table}

1 Fertilization rates of bovine oocytes

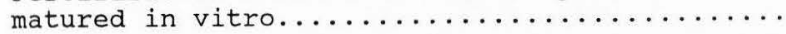

2 cleavage rates of bovine oocytes

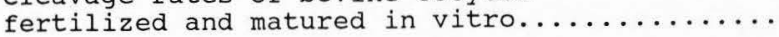




\section{LIST OF FIGURES}

Figure

Page

1 Bovine embryo development to morula stage ...... 23

2 Bovine embryo development to blastocyst stage.... 24

3 Bovine embryo development to hatched

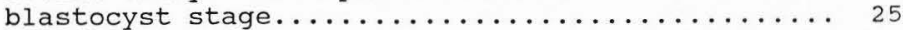

4 Development of morula stage bovine embryos

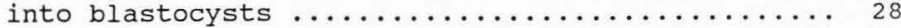

5 Development of blastocyst stage bovine embryos

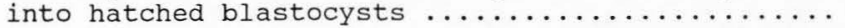


ABSTRACT

\author{
Effect of Various Growth-Promoting Factors \\ on Preimplantation Bovine Embryo \\ Development in vitro
}

by

\begin{abstract}
Mark Randall Flood, Doctor of Philosophy
Utah State University, 1992
\end{abstract}

Major Professor: Dr. Thomas D. Bunch

Department: Animal, Dairy and Veterinary Sciences

The purpose of this research was to define the effects of various growth-promoting factors on in vitro embryonic development of in vitro matured and in vitro fertilized bovine embryos. The control medium was a chemically defined medium which improves the possibility of closely determining the in vivo conditions the embryo is actually exposed to. The growth-promoting factors tested in this experiment included transferrin, IGF-I (insulin-like growth factor-one), IGF-II (insulin-like growth factor-two), TGF- $\alpha$ (transforming growth factor-alpha), TGF- $B 1$ (transforming growth factor-beta1), PDGF (platelet derived growth factor), EGF (epidermal growth factor), NGF (nerve growth factor), and bFGF (basic fibroblast growth factor). Transferrin was included at 10 micrograms/milliliter, while all other factors were utilized at 10 nanograms/milliliter in the control medium. 
Bovine cumulus-oocytes were retrieved from slaughterhouse ovaries and were matured in Medium-199 containing $10 \%$ fetal bovine serum for 24 hours at $39^{\circ} \mathrm{C}$ in a $5 \% \mathrm{CO}_{2}$ atmosphere. Frozen-thawed bull sperm were swim-up separated and capacitated in medium containing heparin for 3 hours prior to insemination. Gametes were co-incubated for 18 hours and then cumulus cells were stripped from the ova. Ova which did not cleave were removed from culture 36 hours after insemination and were stained for evidence of fertilization. Embryos were cultured in one of the 10 conditions (including control) described above. A total of 150 total oocytes were cultured per treatment for a total of 10 days. EGF improved embryo development, while TGF-BI and TGF- $\alpha$ only slightly improved embryo development compared to the control. All other factors tested did not have a beneficial effect on embryo development in this culture medium.

In summary, EGF improved in vitro development of bovine embryos obtained from in vitro maturated and in vitro fertilized bovine oocytes. Other factors which were tested did not significantly improve in vitro bovine embryo development. Further experiments are necessary for determining the requirements of bovine embryos in vitro. 
The effects of various factors on early embryonic development in vitro have been investigated for many years. However, the results from these studies are confounded because the culture media were supplemented with bovine serum albumin (BSA) or serum, which are not chemically defined substances. Recently, researchers isolated an unknown rabbit embryotrophic factor from BSA and characterized it as being citrate (1). Therefore, research on this topic has been limited by the lack of an adequately defined culture medium that allows development of bovine embryos in vitro.

The main source of large numbers of bovine embryos is from ovaries collected at an abattoir. The ovaries are maintained at $25^{\circ} \mathrm{C}$ for up to 4 hours, since research suggests that ovaries stored at $25^{\circ} \mathrm{C}$ contain more viable oocytes than do ovaries stored at $37^{\circ} \mathrm{C}$ or $4^{\circ} \mathrm{C}$ (2). oocytes are collected from 2-8 millimeter (mm) surface follicles and are matured (IVM) and fertilized (IVF) in vitro. The development of IVM techniques (3) has greatly enhanced the use of IVF to produce large numbers of transferrable bovine embryos. The utilization of IVM will also be important in the development of large-scale cloning methods (nuclear transplantation; see ref. 4). Also, IVM and IVF will provide an appropriate amount of embryos for recombinant DNA studies (transgenic animal production) for improving livestock production or for obtaining animals that produce unique human proteins for pharmacological purposes (5). Therefore, IVM and IVF 
techniques can be utilized to produce bovine embryos for in vitro culture studies.

Recently, seidel et al. (6) reported the use of a chemically defined medium in which approximately $20 \%$ of cleaved embryos develop to the blastocyst stage. The formulation for this chemically defined medium (CDM) is in appendix III. Briefly, the CDM contains salts, 3 energy sources (glucose, lactate and pyruvate), 20 amino acids, polyvinyl alcohol (PVA) as a large molecule, EDTA, insulin, and gentamycin sulfate as an antibiotic. Insulin is included in the media because it increases the number of inner cell mass cells (ICMs) in mouse blastocysts (7). Therefore, this medium can be utilized as a control medium for testing the effect of various media supplements on the in vitro development of bovine embryos. 


\section{OBJECTIVES}

The purpose of this research was to define the effects of various growth-promoting factors on in vitro embryonic development of IVM-IVF produced 1-cell bovine embryos. 


\section{REVIEW OF LITERATURE}

The development of a chemically defined medium allows measurement of the effect of growth-promoting factors on in vitro embryo development. Some factors that may be important in some aspect of embryonic development include transferrin (Tf), EGF (epidermal growth factor), TGF- $\alpha$ (transforming growth factor-alpha), TGF-BI (transforming growth factorbetal), IGF-I (insulin-like growth factor-one), IGF-II (insulin-like growth factor-two), PDGF (platelet derived growth factor), bFGF (basic fibroblast growth factor), and NGF (nerve growth factor). If a factor is not produced endogenously by the embryo, it is either supplied from an exogenous source (i.e., the culture medium or maternal environment) for proper embryo development or is not important for preimplantation development. However, if a factor is produced endogenously by the embryo, supplementation is probably not necessary for adequate embryo growth. It is appropriate to separately discuss each of these factors as they pertain to embryo development in vitro and in vivo.

Transferrin

virtually every cell type examined in a serum-free culture has been found to respond to transferrin supplementation (8). In some instances the transferrin supplementation can be mimicked by addition of ferrous sulfate to the culture medium $(9,10)$. Transferrin either acts as a 
detoxifying protein, by removing toxic metals from the medium (11), or directly acts on the cells in culture. The critical function of transferrin within cells may be in supplying iron for energy production via the electron transport pathway. However, recent research suggests that transferrin is not beneficial for the culture of bovine $(6,12)$ or mouse embryos (13). Independent of the mode of action of transferrin in culture, further research is needed to validate the results of transferrin supplementation on bovine embryo cultures.

\section{Epidermal Growth Factor}

Epidermal growth factor (EGF) is a factor which is a potent mitogen for ectodermal and mesodermal cell types (14, 15) that also appears to be important in early embryo development. EGF and members of the EGF family (TGF- $\alpha$ and amphiregulin) can bind to EGF receptors to elicit an increase in tyrosine phosphorylation $(16,17)$. This phosphorylation is a critical step in the signal transduction pathway. The response of the tyrosine phosphorylation to EGF receptor binding can be reversed by a tyrophostin compound, RG 50864 (18, 19). Research suggests that this compound (RG 50864) decreases EGF-stimulated mouse embryo development in vitro $(18,19)$.

EGF has been reported to promote germinal vesicle breakdown (GVBD; an important step in oocyte maturation) in a dose dependent manner (20). The GVBD in vitro only occurs when oocytes are cumulus-intact $(21,22)$. Rose et al. 
also reported that EGF binds to both granulosa and cumulus cells and that follicular fluid inhibited EGF binding. Coskin et al. (23) describe an increase in cleavage rate and formation of 4 - to 8 -cell bovine embryos when oocytes were cultured in $10 \mathrm{ng} / \mathrm{ml}$ EGF. The production of an EGF-like substance has been observed from ovarian thecal/interstitial cells (24) and porcine follicular fluid (25). Therefore, EGF may be physiologically important in oocyte maturation and early embryo development.

Paria and Dey (26) reported that EGF supplementation improved development of two-cell mouse. embryos to the blastocyst stage at concentrations of 2,4 and $10 \mathrm{ng} / \mathrm{ml}$. These researchers also reported that cell numbers per blastocyst were increased when EGF was added to the culture medium. However, Colver et al. (13) reported that EGF supplementation had no effect on cell numbers per blastocyst. Supplementation with EGF plus TGF-B1 yielded higher development of mouse two-cells to blastocysts than did either supplemented alone or in combination with IGF-I (26). However, research by colver et al. (13) suggests that EGF supplementation stimulated mouse embryo development only at 10 $\mathrm{ng} / \mathrm{ml}$, but not at lower concentrations.

Also, EGF stimulates the rate of blastocoel expansion of mouse embryos, possibly through activating the sodium/hydrogen ion exchanger on trophoderm cells (27). In addition, Paria and Dey (26) provided evidence that EGF binds specifically to 
trophoderm and not to ICM cells.

An improvement in hatching rate was also observed by Paria and Dey (26), but was not observed by Colver et al. (13) using mouse embryo cultures. This increased rate of zona hatching could be, in part, due to an increase in plasminogen activator activity of the trophoderm cells (28). However, in many cases the mouse embryo is not a good model for other mammalian embryos. Researchers have reported that EGF did not improve development of cultured bovine embryos into blastocysts, but more embryos did hatch when supplemented with $\operatorname{EGF}(12,29)$.

The embryo culture data correspond nicely to reports that EGF is not endogenously transcribed or synthesized by the early mouse embryo (30), and that functional EGF receptors have been located on the preimplantation trophoderm of pig embryos (31).

Estrogen also appears to be important in EGF regulation within the in vivo environment. Estrogen regulates synthesis of EGF in mouse uterine epithelial cells (32) and regulates EGF receptor formation in uterine tissues (33). Additional research suggests that EGF can stimulate prostaglandin secretion in pig uterine epithelial cell cultures (34).

A role for EGF in implantation has also been suggested (35). In addition, physiologically active receptors for EGF have been located on postimplantation mouse embryos (36). Therefore, EGF is a factor which may be important in 
early embryo development. Further investigations are necessary to determine the role of EGF in preimplantation embryo development.

Transforming Growth Factor-alpha

Transforming growth factor-alpha (TGF- $\alpha$ ) is a 50-aminoacid polypeptide that is member of the ancestral family of growth factors including EGF (16). TGF- $\alpha$ is actually $40 \%$ homologous to EGF (37). TGF- $\alpha$ at concentrations of 2,4 and $10 \mathrm{ng} / \mathrm{ml}$ improves the rate of development of mouse 2-cell embryos into blastocysts (26). Mouse blastocysts also had an increase in cell number when medium was supplemented with TGF$\alpha$ (26). In addition, the rate of blastocoel expansion in mouse embryos is stimulated by $T G F-\alpha$ (27). These effects are thought to be mediated through the EGF receptor because RG 50864 inhibits the positive effects of TGF- $\alpha$ on embryo development (17). TGF- $\alpha$ receptors have been found only on trophoderm and not on ICM cells (26). Furthermore, research suggests that $16-$ cell bovine embryos supplemented with $1 \mathrm{ng} / \mathrm{ml}$ TGF- $\alpha$ have improved development to the blastocyst stage when compared to controls (38).

The embryo culture results are interesting considering that TGF- $\alpha$ is synthesized by preimplantation mouse embryos (30). Because embryos cultured in groups develop at a higher rate than do embryos cultured individually (26), there is speculation that TGF- $\alpha$ acts in an autocrine manner. The TGF$\alpha /$ EGF receptors are located on cells cultured from 
trophectoderm origin and not from cells of ICM origin (26). TGF- $\alpha$ may also be important in maintaining uterine epithelial growth early in the pregnancy (39) and may be critical for fetal and neonatal development (16). TGF- $\alpha$ is also known to be angiogenic (40) and the highest density of uterine capillary beds is opposite the implantating embryo (41). In addition, at the time of implantation there is a surge of estrogen which increases EGF receptor expression in the uterus (33). Thus, TGF- $\alpha$ may be important in implantation events in vivo. However, the possibility that TGF- $\alpha$ may also be important in early preimplantation embryo development warrants the investigation of this growth factor's effect on bovine embryos in culture.

Transforming Growth Factor-betal

Transforming growth factor-betal (TGF-BI) is a member of a large gene family of potent mesoderm inducers that also appears to be important in early embryo differentiation (26) . TGF-BI was originally purified from human platelets as a homodimeric peptide, based on its ability to induce anchorageindependent growth of normal fibroblast indicator cells (42). The function of $T G F-\beta$ may be in stimulating extracellular matrix production and protease activity. TGF-BI supplemented at 2 and $4 \mathrm{ng} / \mathrm{ml}$ improved the percentage of two-cell mouse embryos that developed to blastocysts, without increasing cell numbers per blastocyst (26). These researchers also proved that supplementation with TGF-BI plus EGF stimulated mouse 
embryo development synergistically. The role of TGF-BI in blastocyst formation could be mediated by causing differentiation of trophoectoderm cells and establishing tight junctions in this cell layer (43). The mode of TGF-BI action is likely different from that of EGF and TGF- $\alpha$ since the tyrosine phosphorylation inhibitor, RG50864, does not effect TGF-B1 stimulated embryo development (17). However, Keefer (29) failed to duplicate these results in bovine embryo cultures using $2 \mathrm{ng} / \mathrm{ml}$ concentrations.

The embryo culture data become even more confusing when one considers that $T G F-B I$ is transcribed by the preimplantation mouse embryo (30). The action of TGF- 31 may also be autocrine, since mouse embryos cultured individually do not exhibit the positive influence of TGF-BI that is observed when embryos are cultured in groups (26).

TGF-B1 may also be involved in uterine development during early pregnancy. Researchers have localized TGF- BI to the apical surface of bovine uterine luminal epithelium, especially in epithelial cells from pregnant animals (39). Also, TGF- $B$ is known to be angiogenic (44) and the highest concentration of capillary beds in the uterus is near the implantating blastocyst (41). Thus, TGF- $\beta$ may be important in embryo implantation.

However, conflicting research on the possible role of TGF-B1 on early embryos in culture necessitates that future research be conducted in this area. 
Insulin-Like Growth Factor-one

Insulin-like growth factor-one (IGF-I), also known as somatomedin $\mathrm{C}$, is important in sulfate uptake in cartilage (45). IGF-I is expressed by ovine oviductal cells in culture (46) and IGF-I expression is hormonally regulated by estrogen and progesterone in the pig uterus (47). Research suggests that IGF-I receptors and transcripts for IGF-I receptors have been located in the preimplantation embryo $(30,31,48,49)$. However, Corps et al. (31) suggest that these IGF-I receptors are not functional in the pig embryo. Also, mouse blastocysts may respond to insulin and IGF-I through the insulin receptor (50). In addition, mouse embryos do not synthesize IGF-I during any preimplantation stage (30).

However, results in mouse embryo cultures conflict with the suggestive information described above. Paria and Dey (26) reported that IGF-I did not improve development of twocell mouse embryos cultured to blastocysts except when supplemented along with EGF or TGF-BI. Since there may be IGF-I present in secretions from the oviduct and uterus and receptors are present on the embryo, there may be a function of IGF-I during embryo development that has yet to be examined.

Also, since no data is available on the effect of IGF-I on in vitro bovine embryo development, further investigation is needed in this area. 
Insulin-Like Growth Factor-two

Insulin-like growth factor-two (IGF-II), also known as somatomedin A and multiplication stimulating activity (MSA), is important in proliferation of mesenchymal cells (45). Transcripts for IGF-II receptors have been isolated from mouse embryos (30). IGF-II expression has been observed in pig uterine endometrium and is controlled by estrogen and progesterone distinct from IGF-I regulation (47).

strangely, IGF-II is also synthesized in the early preimplantation mouse embryo (30). The IGF-II gene is also expressed in trophoectoderm and its derivatives after implantation (51). Subsequently, IGF-II transcripts are found in the extraembryonic and embryonic mesoderm and in the lining of the foregut. Therefore, IGF-II is synthesized by embryonic and uterine cells.

IGF-II may be important in implantation or other undetermined embryological events. The role of IGF-II in embryo development remains unclear. Therefore, it is of interest to determine if there are any effects of IGF-II on bovine embryo development in vitro.

Platelet Derived Growth Factor

Platelet derived growth factor (PDGF) is a factor that normally stimulates proliferation of T-lymphocytes (45) and is a chemoattractant for fibroblast and smooth muscle cells (52). However, PDGF may also be important in early embryonic development. PDGF has been isolated from fluid in which 
bovine oviductal cells were cultured (53). In addition, the length of the fourth cell cycle (from 8-cell to 16-cell stage) in bovine embryos was shortened when medium was supplemented with PDGF (38). Thus, it appears that embryos at the stage of zygotic transition may be signalled to initiate the first embryonically-controlled cleavage. However, PDGF had no effect on mouse preimplantation embryo development in defined medium (13).

The mouse culture data is not surprising considering that PDGF is synthesized by the preimplantation mouse embryo (30) However, PDGF was not detected in media from mouse blastocyst cultures, but was detected in a medium from human blastocyst cultures (54). The PDGF assay may have not been sensitive enough for the mouse embryo cultures or other isoforms of PDGF may have been present that could not be detected by this assay.

It appears that PDGF can be produced in embryonic and oviduct cells. Therefore, PDGF may be important in early embryonic development and implantation. However, the possible role of PDGF in blastocyst stage embryos is unclear. Thus, the effect of PDGF on bovine embryo development needs to be clarified by conducting more research on this topic.

\section{Basic Fibroblast Growth Factor}

Basic Fibroblast Growth Factor (bFGF) stimulates mesenchymal cell proliferation (45) and controls the proliferation and differentiation of mesoderm and neuro- 
ectoderm cells (55). Fibroblast cells respond to bFGF in a dose dependent manner, with a plateau of growth being observed at $20 \mathrm{ng} / \mathrm{ml}$ concentrations (55). Normal human endometrium contains transcripts of bFGF, while peripheral leucocytes and platelets did not contain these transcripts (56). Therefore, it is possible that uterine endometrium could produce bFGF. In addition, bFGF is not synthesized by preimplantation mouse embryos $(30)$.

However, embryo culture data suggests that bovine 16-cell embryos were not stimulated to develop to blastocysts, when compared to controls, by $50 \mathrm{pg} / \mathrm{ml}$ bFGF supplementation (38). It is possible that this concentration is not sufficient to promote embryonic development or that bFGF is necessary for embryonic development at earlier stages than were examined. However, other research suggests that FGF supplemented at 5 $\mathrm{ng} / \mathrm{ml}$ improves development of mouse embryos (13).

Therefore, the effect of bFGF on early embryos remains uncertain. Research is necessary to clarify the role, if any, in early embryo development.

\section{Nerve Growth Factor}

Nerve growth factor (NGF) is important in the development of sensory and sympathetic neurons (44). NGF has been detected at elevated levels in semen samples. Research also suggests that NGF is not synthesized by the preimplantation mouse embryo (27). In addition, embryonal carcinoma stem cells specifically bind NGF (57). Therefore, there may be a 
role for NGF in fertilization and/or embryonic development. NGF has not been utilized as a supplement for embryo cultures to date. Thus, the role for NGF in embryo development, if any, needs to be determined.

\section{Summary of Literature}

The effect of many growth factors on embryo development has been masked for years because cultures contained undefined components that were embryotrophic. The development of a defined culture medium will aid in the search for the roles of many growth-promoting factors on embryonic development. Other chemically defined media have been described for hamster (58, $59,60)$, rabbit (61), and bovine embryos $(62,63,64)$. one of these media may prove more beneficial for bovine embryos cultured in vitro. However, further testing of these media will be necessary to distinguish any differences in developmental rates.

It is important to note that a lack of a positive response on development does not necessarily mean that a factor is not important in early embryo development. There simply may be other components in the culture medium which are rate limiting. Thus, the addition of any other compound will not appear to improve embryo development in vitro. This may be true for any or all of the above mentioned chemically defined media formulations. However, research on the effect of the different growth-promoting factors described above on enbryonic development may not yield significantly new 
information because the conditions of the culture medium are not yet optimized. Therefore, future research may be necessary to modify chemically defined media formulations to maximize embryo developmental rates.

Research on defining compounds necessary for embryonic development will aid the research in areas of transgenic animal production and nuclear transplantation. Thus, researchers in these areas will have more opportunity for success in their experiments, since more embryos will develop to the desired stages from the same number of original material.

In addition, since extrapolation from research on mouse embryo development is generally risky, it would be beneficial to determine the effect of these factors on bovine embryo development directly. 


\section{MATERIALS AND METHODS}

Ovaries were obtained from E.A. Miller's abattoir (Hyrum, UT) and transported to the Animal, Dairy and Veterinary Sciences Department's Meats and Physiology Laboratory (corner of 800 east and 1400 north in Logan, UT) in sterile saline $\left(0.9 \% \mathrm{w} / \mathrm{v}\right.$ sodium chloride) maintained at $22-24^{\circ} \mathrm{C}$. Upon arrival at the lab, ovaries were rinsed three times in fresh sterile saline. Within 5 hours of collection, follicular contents were aspirated from 2-8 $\mathrm{mm}$ surface follicles and collected in a $15 \mathrm{ml}$ centrifuge tube. Aspiration was with a 20 gauge 1 1/2" needle attached to a $10 \mathrm{ml}$ syringe. oocytes were allowed to settle to the bottom of the tube and then follicular fluid was discarded. Oocytes were then washed in Dulbecco's phosphate buffered saline (D-PBS; Gibco Laboratories, Grand Island, NY) supplemented with $0.5 \%$ fraction $V$ bovine serum albumin (BSA; Sigma chemical, st Louis, MO; catalog \# A-9418). Oocytes with surrounding cumulus complexes (cumulus-oocytes) were then collected and washed three times in fresh D-PBS. Cumulus-oocytes were then washed three additional times in Medium 199 (Gibco, catalog \# 380-2340AG) with $10 \%$ FBS (fetal bovine serum; Hyclone Laboratories, Logan, UT; lot \# 1078) (supplemented Medium 199). Twenty to 25 cumulus-oocytes were incubated in $0.5 \mathrm{ml}$ drops of supplemented Medium 199 in $1.5 \mathrm{ml}$ wells of a NUNCLON multidish (4-well dish). Medium was covered with $0.5 \mathrm{ml}$ sterile-filtered paraffin oil. The oocytes were allowed to 
mature for $23-25$ hours in culture at $39^{\circ} \mathrm{C}$ in a humidified, $5 \%$ carbon dioxide atmosphere.

After the oocytes were matured, one frozen straw from each of two IVF-tested, fertile bulls (Select sires, Logan, UT) were thawed in a $35^{\circ} \mathrm{C}$ water bath for 30 seconds. Sperm were swim-up separated (65) by overlaying the semen with $1 \mathrm{ml}$ of Sp-TALP (65; formulation in Appendix II.) containing 5 units $/ \mathrm{ml}$ heparin at $39^{\circ} \mathrm{C}$. Motile sperm were then separated after 1 hour by removing the Sp-TALP layer while being careful to leave the unwanted sperm solution on the bottom of the tube. Capacitation for an additional 2 hours was conducted in fresh Sp-TALP medium at $39^{\circ} \mathrm{C}$.

The mature oocytes were washed three times in Fert-TALP (65; formulation in Appendix I.) and transferred into $0.3 \mathrm{ml}$ drops of Fert-TALP containing $5 \mathrm{~mm}$ caffeine. Fertilization occurred in NUNCLON 4-well dishes with medium being covered by $0.5 \mathrm{ml}$ sterile-filtered paraffin oil. Gametes were coincubated for 18 hours at $39^{\circ} \mathrm{C}$, with 20-25 cumulus-oocytes being cultured with a final sperm concentration of $2 \times 10^{6}$ sperm/ml. After fertilization, cumulus cells were stripped from the ova by pipetting through a small bore pipet and ova were allocated into one of ten media treatments to assess effects on bovine embryo development in culture.

The treatments were as follows: 1) chemically defined medium (CDM; formulation in Appendix III.) alone [Control]; 2) $\mathrm{CDM}+10 \mathrm{ug} / \mathrm{ml}$ bovine transferrin ( $\mathrm{Tf}$, HyClone, product 
\#A21830021); 3) CDM + $10 \mathrm{ng} / \mathrm{ml}$ EGF (Sigma, catalog \# E-1264, lot \#120H0663); 4) $\mathrm{CDM}+10 \mathrm{ng} / \mathrm{ml} \mathrm{TGF}-\alpha$ (Sigma, catalog \# $\mathrm{T}-$ 7533, lot \#90H8910; 5) CDM + $10 \mathrm{ng} / \mathrm{ml} \mathrm{TGF}-\beta 1$ (Sigma, catalog $\#$ T-1654, lot \# 120H0488); 6) CDM + $10 \mathrm{ng} / \mathrm{ml}$ IGF-I (HyPep ${ }^{T M}$ Long $\mathrm{R}^{3}$ IGF-I, HyClone); 7) $\mathrm{CDM}+10 \mathrm{ng} / \mathrm{ml}$ IGF-II (Sigma, catalog \# I-2139, lot \# 90H89202); 8) CDM + $10 \mathrm{ng} / \mathrm{ml}$ PDGF (Sigma, catalog \# P-8147, lot \# 120H-0487);9) CDM + $10 \mathrm{ng} / \mathrm{ml}$ bFGF (Sigma, catalog \# F-5392, lot \# 11H-89351); and 10) CDM $+10 \mathrm{ng} / \mathrm{ml} \mathrm{NGF}$ (Sigma, catalog \# N-0513, lot \# 51H-88361).

Non-cleaved ova were removed 48 hours after initiation of fertilization culture (30 hours after placed into separate treatments), then fixed and stained in $2 \%$ aceto-orcein stain to assess fertilization. These results were used to determine fertilization rates for each treatment. A total of 150 oocytes were cultured per treatment in 6 replicates. Embryos were cultured for a total of 10 days at $39^{\circ} \mathrm{C}$. Embryonic development was assessed every other day and approximately $1 / 2$ of the media was exchanged with fresh media at that time. The effect of each factor on bovine embryo development in vitro was determined by comparing percentages of total oocytes that achieved morula, blastocyst and hatched blastocyst stages of development. Embryos were considered to be morula stage if they were tightly compacted. Blastocyst stage embryos expanded the zona pellucida beyond the normal size of the zona in earlier stage embryos. Results were compared by Chi square analysis with significance being reported at $\mathrm{P}<.05$. 
RESULTS

The effect of various medium supplements on bovine embryo development is summarized herein. Because fertilization rates (Table 1) and cleavage rates (Table 2) were similar (P>.05) between treatments, comparisons of development on the basis of total oocytes was valid. The fertilization rate for each supplement was determined by dividing the number of embryos cleaved plus the number of normal fertilizations (two pronuclei present) by the total number of oocytes in each treatment. The fertilization rate was highest in the PDGF supplemented embryos $(82.6 \%)$ and lowest in IGF-II supplemented embryos (80.0\%), although there were no significant differences between treatments $(\mathrm{P}>.05)$. The cleavage rate (cellular division) for each supplement was determined by dividing the number of embryos $\geq 2$ cell stage of development by the total number of oocytes in each treatment. Rate of cleavage was highest in PDGF and TGF- $\alpha$ supplemented embryos (78.0\%) and lowest in Tf, IGF-I and NGF supplemented embryos (76.0\%), although there were no significant differences between supplements (P>.05).

Data on bovine embryo development to the morula (Figure 1), blastocyst (Figure 2), and hatched blastocyst (Figure 3) are described below. There were no differences (P>.05) in embryo development at the morula stage (Figure 1), although there was a tendency of EGF supplementation to improve embryo development when compared to other treatments. The lowest 
Table 1. Fertilization rates of bovine oocytes matured in vitro

\begin{tabular}{lrr}
\hline Treatment & $\begin{array}{l}\text { Number of Fertilized } \\
\text { Embryos }\end{array}$ \\
\hline Control & 122 & $(81.3)$ \\
Transferrin & 121 & $(80.6)$ \\
EGF & 122 & $(81.3)$ \\
TGF- $\alpha$ & 123 & $(82.0)$ \\
TGF-BI & 123 & $(82.0)$ \\
IGF-I & 121 & $(80.6)$ \\
IGF-II & 120 & $(80.0)$ \\
PDGF & 124 & $(82.6)$ \\
bFGF & 123 & $(82.0)$ \\
NGF & 121 & $(80.6)$
\end{tabular}

* Percent of 150 total oocytes/supplement

a Values between supplements are similar (P>.05) 
Table 2. Cleavage rates of bovine embryos fertilized and matured in vitro

\begin{tabular}{lcc}
\hline Treatment & $\begin{array}{c}\text { Number of Embryos } \\
\text { Cleaved }\end{array}$ \\
\hline Control & 115 & $(76.6)$ \\
Transferrin & 114 & $(76.0)$ \\
EGF & 116 & $(77.3)$ \\
TGF- $\alpha$ & 117 & $(78.0)$ \\
TGF-B1 & 116 & $(77.3)$ \\
IGF-I & 114 & $(76.0)$ \\
IGF-II & 115 & $(76.6)$ \\
PDGF & 117 & $(78.0)$ \\
bFGF & 116 & $(77.3)$ \\
NGF & 114 & $(76.0)$ \\
\hline
\end{tabular}

* Percent of 150 total oocytes/supplement

a Values between supplements are similar ( $P>.05$ ) 
Supplement

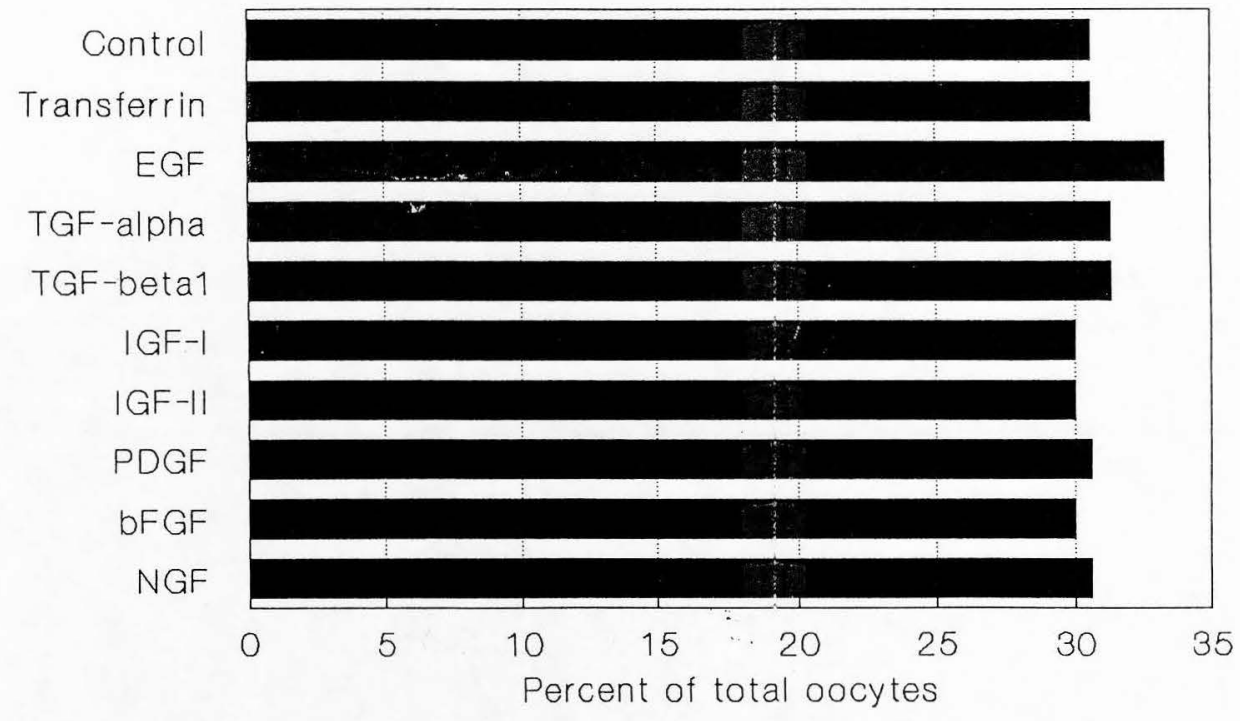

Figure 1. Bovine embryo development to morula stage Values are similar (P>.05) 
Supplement

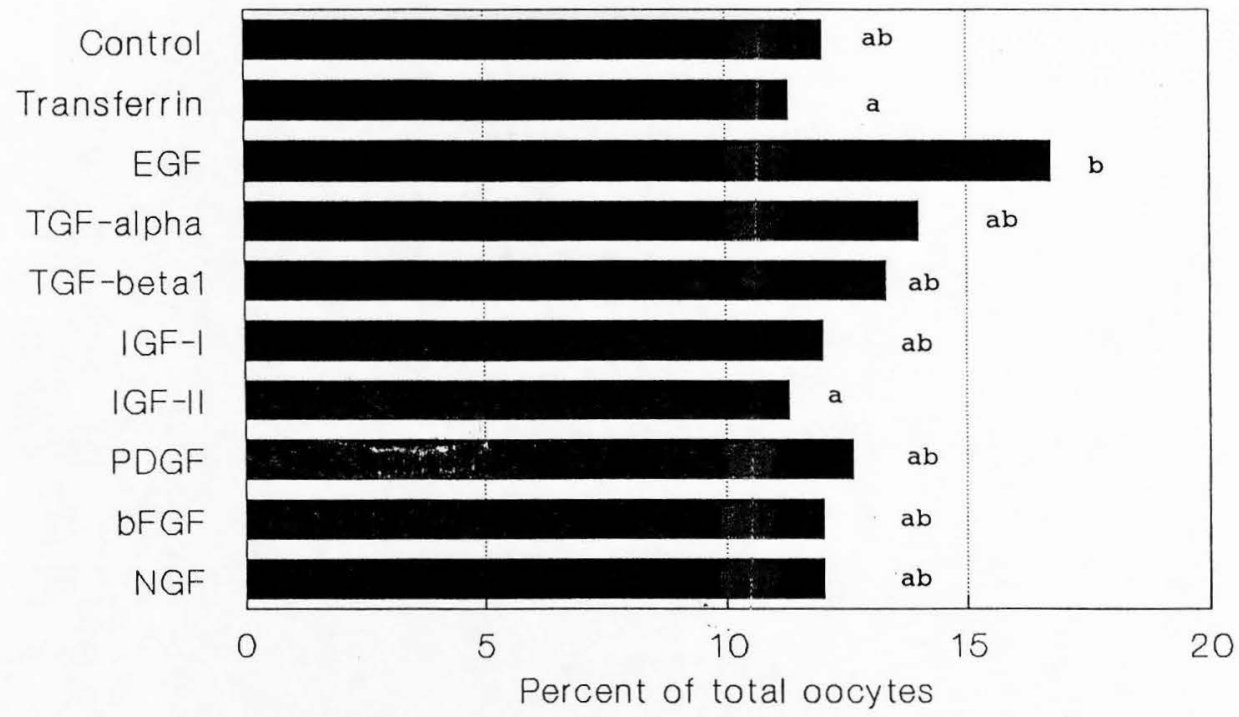

Figure 2. Bovine embryo development to blastocyst stage ${ }^{a b}$ Treatments with different letters are different $(P<.05)$ 
Supplement

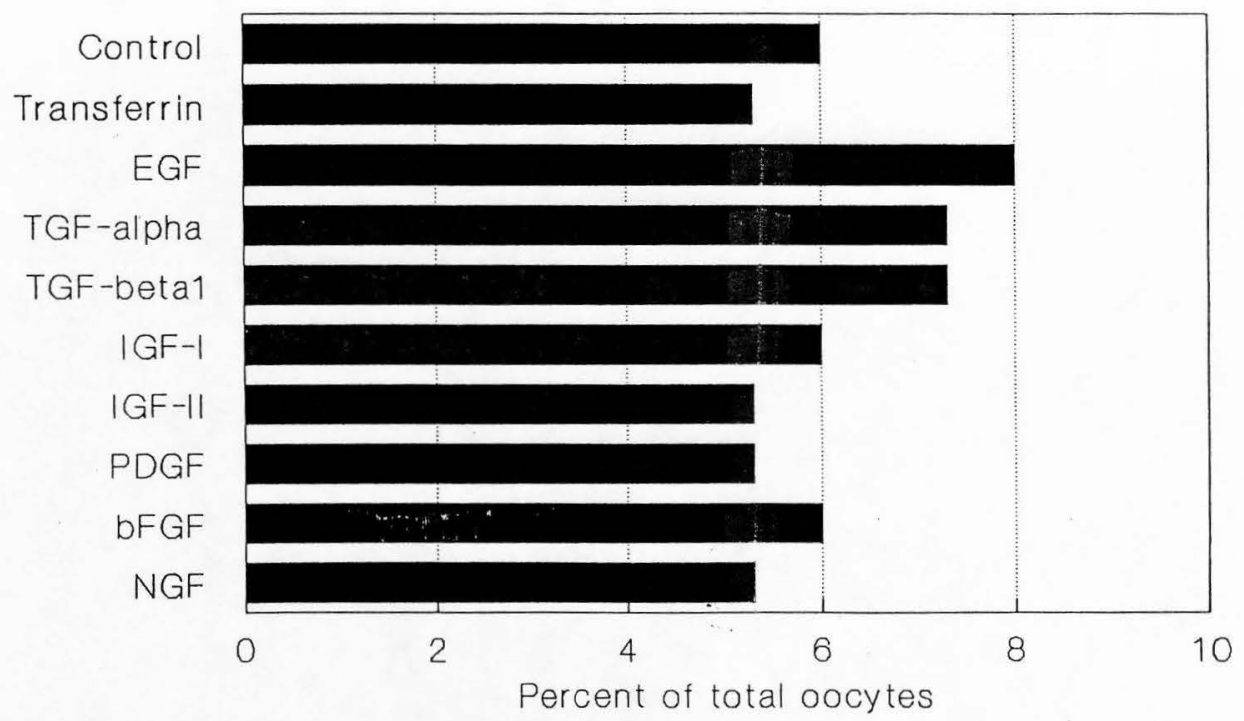

Figure 3. Bovine embryo development to hatched blastocyst stage

Values are similar (P>.05) 
rate of morula formation was observed with embryos cultured in IGF-I, IGF-II and bFGF (30.0\%; Figure 2).

However, EGF supplementation improved development of IVMIVF produced bovine embryos to the blastocyst stage (16.7\%), but this improvement was statistically significant $(\mathrm{P}<.05)$ compared only to IGF-II and Tf supplementation (11.3\%; Figure 2). In addition, supplementation with EGF approached significance $(\mathrm{P}=.08)$ when compared to control, IGF-I, bFGF, and NGF (12.0\%) supplementation at the blastocyst stage of development (Figure 2).

EGF treatment also slightly $(\mathrm{P}=.09)$ improved hatching rate $(8.0 \%)$ when compared to transferrin, IGF-II, PDGF, and NGF supplementation (5.0-5.3\%; Figure 3). There were, however, no significant differences in the embryo development to the hatched blastocyst stage between treatments (P>.05). The lowest rates of hatching were observed for embryos cultured in Tf, IGF-II, PDGF, and NGF.

TGF $-\alpha$ and TGF- $\beta 1$ supplementation slightly improved bovine embryo development to blastocyst and hatched blastocyst stages when compared to all supplements except EGF, but this effect was not statistically significant (P>.05).

EGF supplementation improved $(\mathrm{P}<.05)$ the development of morula stage embryos into blastocysts (Figure 4) compared to embryos in control, Tf, IGF-I, IGF-II, bFGF, and NGF treatments. In addition, this developmental rate was slightly improved $(\mathrm{P}=.07)$ by EGF supplementation when compared to PDGF 
supplementation. Supplementation with TGF- $\alpha$ and TGF- BI did not improve the percentage of blastocysts from morula when compared to all other treatments (P>.05).

TGF-BI improved $(\mathrm{P}<.05)$ the percentage of embryos hatching from blastocyst stage embryos (Figure 5), compared to PDGF and NGF supplemented embryos. TGF- $\alpha$ also improved $(\mathrm{P}<.05)$ this hatching rate (Figure 5) when compared to PDGF supplemented embryos. All other combination of treatment comparisons had similar hatching rates when compared to each other $(\mathrm{P}>.05)$. 
Supplement

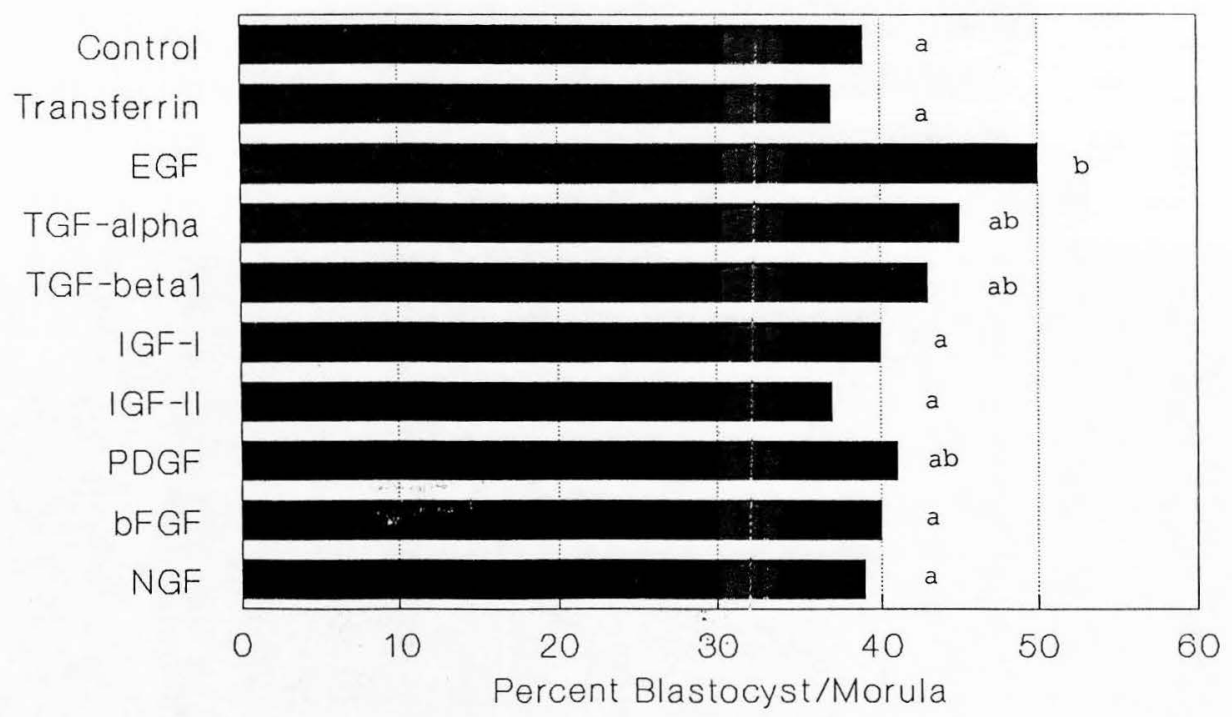

Figure 4. Development of morula stage bovine embryos into blastocysts

${ }^{a b}$ Treatments with different letters are different $(\mathrm{P}<.05)$ 
Supplement

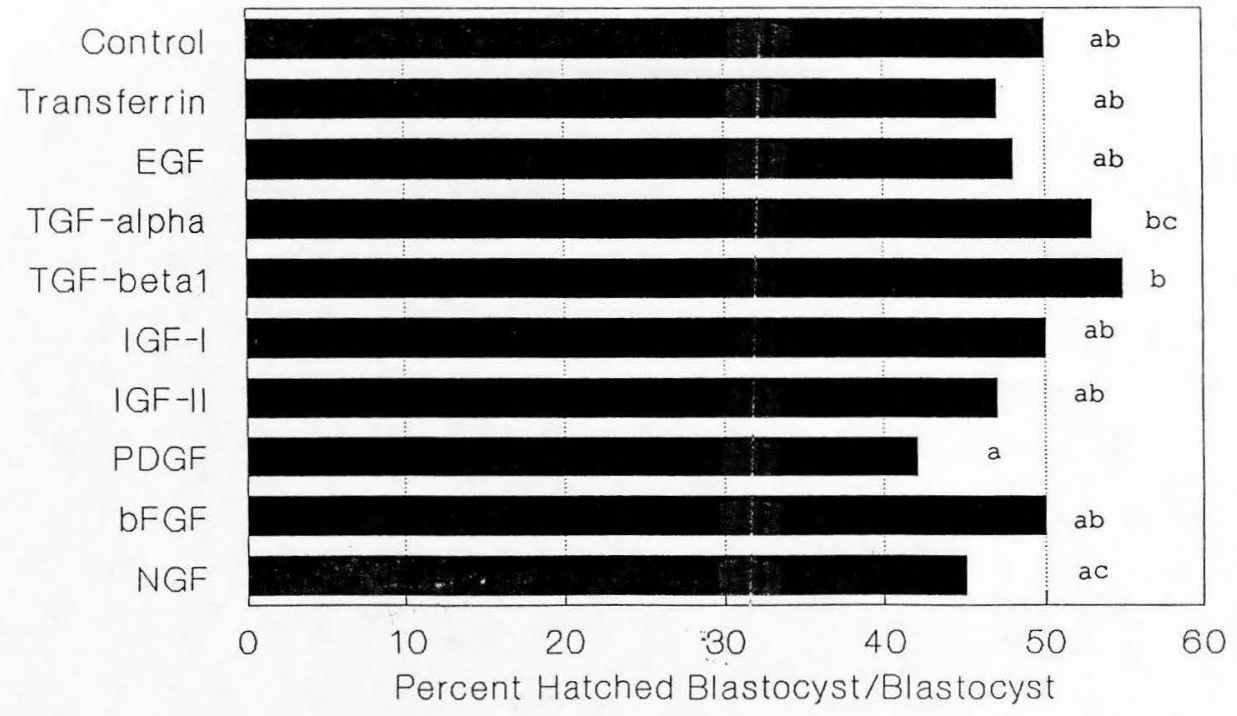

Figure 5. Development of blastocyst stage bovine embryos into hatched blastocysts

${ }^{\circ}$ Treatments with different letters are different $(P<.05)$ 
DISCUSSION

The development of a chemically defined medium allows measurement of the effect of growth-promoting factors on in vitro embryo development. The data for the control group are similar to results reported by zhang et al. (66) and seidel et al. $(6,64)$ using the same chemically defined medium used as a control in this experiment. However, Yang and Seidel (67) reported somewhat higher development to the blastocyst stage (33-35\% from fertilized embryos) using this medium.

The results with transferrin supplementation are similar to what other researchers have described with bovine $(6,12)$ and mouse embryos (13). While other cells thrive in transferrin supplemented medium, bovine embryos apparently do not require transferrin for preimplantation development.

Bovine embryo development to the blastocyst stage from morula stage embryos was stimulated by EGF supplementation. A probable mechanism involves EGF stimulating blastocoel formation through the specific binding of EGF to trophoderm cells, since there have been reports that EGF binds to trophodermal cells in mouse (26) and pig embryos (27). This binding may activate the sodium/hydrogen ion exchanger on trophoderm cells (27). The results obtained here correspond to data in the mouse $(13,26)$, but not to other research utilizing bovine embryos $(12,29)$. Takagi et al. reported that embryos cultured in Medium 199 plus mouse EGF, human transferrin, and bovine insulin did not stimulate bovine 
embryo development to the blastocyst stage from cleaved embryos. Their research also suggests that more embryos which reached the 8 -cell stage continued to blastocyst when supplemented with these growth-promoting factors. However, their research used a different control medium and a different EGF (mouse source) than was utilized in this research (human source). Keefer (29) reported that EGF supplementation did not improve development of 8- to 16-cell bovine embryos to the blastocyst stage, but did improve hatching rate. However, this researcher did not culture embryos from the time of fertilization through development, so there is little to compare it to this experiment. The hatching data from blastocysts suggests that different results were obtained between these experiments.

Supplementation with TGF- $\alpha$ tended to improve bovine embryo development from total oocytes, but this effect was not statistically significant (P>.05). In addition, TGF- $\alpha$ supplementation improved the hatching rate of blastocysts compared to PDGF treated embryos. These results are similar to reports with mouse (26) and bovine embryos (38). TGF- $\alpha$ supplemented at $1 \mathrm{ng} / \mathrm{ml}$ improved $16-\operatorname{cell}$ bovine embryo development to the blastocyst stage (38). The concentration used in this experiment was 10 times higher and the embryos were cultured from fertilization, so comparisons between these research efforts may not be rational. Also, TGF- $\alpha$ does not appear to have any beneficial effects on embryo development 
prior to the $16-\mathrm{cell}$ stage. TGF- $\alpha$ is thought to work via the EGF receptor since there is $40 \%$ homology between these two factors. However, $\mathrm{TGF}-\alpha$ may not bind to EGF receptors with the same affinity as EGF, because TGF- $\alpha$ does not elicit similar rates of blastocoel formation.

The addition of TGF-BI to the culture medium did not statistically improve bovine embryo development from total oocytes. However, TGF-BI supplementation did improve the hatching rate of blastocysts compared to PDGF and NGF supplemented embryos. Results reported here are similar to those from mouse embryo cultures (26). Keefer (29) also indicated that $4-$ to $8-\operatorname{cell}$ bovine embryos did not have improved development when cultured in medium supplemented with $2 \mathrm{ng} / \mathrm{ml}$. In addition, the TGF-BI utilized by Keefer was from a laboratory other than Sigma and was 5 times more dilute than was utilized here. Therefore, it is arduous to accurately compare these results, although statistical significance was similar to results of Keefer (29).

IGF-I supplementation did not improve bovine embryo development in this experiment. This is similar to mouse embryo culture data (26). However, no data on bovine embryo development has been reported with IGF-I supplementation. Several researchers have reported IGF-I receptors on preimplantation embryos $(30,31,48,49)$. The reason that IGF-I does not stimulate embryonic development may be that the receptors are not functional, as has been described for the 
pig embryo (30). There have also been suggestions that IGF-I may affect embryo development via the insulin receptor (50). However, since insulin was already included in the medium, there may not be additional effects on embryo development when IGF-I is also supplemented.

Bovine embryo development was not improved with supplementation of PDGF. Results reported here are similar to mouse embryo culture data (13). This somewhat contradicts research which suggests that the length of the fourth cell cycle (from 8- to 16-cell stage) in bovine embryo development was shortened when embryos were supplemented with $1 \mathrm{ng} / \mathrm{ml}$ PDGF (38). However, these researchers did not report on development to blastocyst stage, so comparisons with this research may not be valid.

Supplementation with bFGF did not improve bovine embryo development in this experiment. The data is similar to research which suggests that development of 16 -cell bovine embryos to blastocysts was not improved with supplementation of $\mathrm{bFGF}$ at $50 \mathrm{pg} / \mathrm{ml}$ (38). However, it contradicts research on mouse embryos which suggests that supplementation with $5 \mathrm{ng} / \mathrm{ml}$ FGF improved development (13). It also appears that bFGF is not important in embryo development prior to the 16-cell stage from the results obtained here.

Addition of IGF-II or NGF to the culture medium did not improve bovine embryo development. This is the first report of culturing preimplantation bovine embryos in IGF-II or NGF, 
so no comparisons can be made. IGF-II receptor transcripts have been isolated from mouse embryos (30). However, these receptors may not be functional or may be necessary for unknown events within the embryo.

A lack of a positive response on development does not necessarily mean that a factor is not important in early embryo development. There may be other components in the culture medium which are rate limiting.

Also, concentrations, half-lives and sources of these growth factors may be crucial for proper activation of embryonic development. Nearly all of the factors were from human sources, except NGF was from mouse origin and bFGF and transferrin were from bovine origin. The recommendation from Sigma chemical is that the growth factors be used within 5-7 days and should not be stored at dilute concentrations. In this experiment media with supplements were made fresh every week, but the half-life of each factor was not determined for these culture conditions. Also, factors were stored frozen at concentrations ranging from $1 \mathrm{ug} / \mathrm{ml}$ to $0.1 \mathrm{mg} / \mathrm{ml}$ after original hydration. Therefore, developmental capacity may not be optimal because some factors were stored at concentrations too dilute, or the half-life in culture was too short.

In addition, TGF- $B 1$ and PDGF are very hydrophobic proteins that tend to stick to glass and plastic, especially at neutral $\mathrm{pH}$ (personal communication with Sigma chemical Company). The inclusion of a carrier protein like BSA is 
suggested for the IGF-I utilized here because of possible absorption to glass or plastic surfaces (personal communication with Hyclone Laboratories). Thus, these three factors may have not indicated a beneficial effect on bovine embryo development because of the above mentioned biochemical properties.

Also, supplementation of growth factors at higher concentrations than were utilized in this experiment may stimulate embryonic development. However, different concentrations of these factors were not tested in this research effort. Combinations of different factors may be synergistic in the development of bovine embryos, but this was not examined in these experiments. 
CONCLUSIONS

In conclusion, the effect of various growth-promoting factors on bovine embryo development in vitro has been described in this research. The data presented here represent progress that has been made in the effort to define embryo culture conditions. However, research still needs to be conducted in many areas to elucidate defined culture conditions which will provide embryonic development similar to, or better than, culture media supplemented with serum, BSA, or co-culture cells. 
REFERENCES

1. Kane, M.T., Morgan, P.M. and Gray, C.W. Identification of the low molecular weight acid-extractable embryotrophic factor from bovine serum albumin as citrate. J. Reprod. Fert. Abstract Series 7:29 (1991).

2. Yang, N.S., Lu, K.H. and Gordon, I. In vitro fertilization (IVF) and culture (IVC) of bovine oocytes from stored ovaries. Theriogenology $\underline{33: 352}$ abstr. (1990).

3. Brackett, B.G. and oliphant, G. Capacitation of rabbit spermatozoa in vitro. Biol. Reprod. 12:260-274 (1975).

4. Gordon, I. and Lu, K.H. Production of embryos in vitro and its impact on livestock production. Theriogenology 33: $77-86$ (1990).

5. Moffat, A.S. Transgenic animals may be down on the pharm. Science 254:35-36 (1991).

6. Seidel, G.E., Jr., Nauta, W. and Olson, S.E. Effects of myoinositol, transferrin, and insulin on culture of bovine embryos. J. Anim. Sci. 69 (Suppl. 1):403 abstr. (1991).

7. Harvey, M.B. and Kaye, P.L. Insulin increases the cell number of the inner cell mass and stimulates morphological development of mouse blastocysts in vitro. Development 110:963-967 (1990).

8. Barnes, D. and Sato, G. Serum-free cell culture: a unifying approach. Cell 22:649-655 (1980).

9. Mather, J.P. and Sato, G.H. The growth of mouse melanoma cells in hormone-supplemented serum-free medium. Exp. Cell Res. 120:191-200 (1979).

10. Wu, R. and Sato, G.H. Replacement of serum in cell culture by hormones: a study of hormonal regulation of cell growth and specific gene expression. J. Tox. Env. Health $\underline{4}: 427-448$ (1978).

11. Barnes, D. and Sato, G. Methods for growth of cultured cells in serum-free medium. Anal. Biochem. 102:255-270 (1980). 
12. Takagi, Y., Mori, K., Tomizawa, M., Takahashi, T.,

Sugawara, S., and Masaki, J. Development of bovine oocytes matured, fertilized and cultured in a serumfree, chemically defined medium. Theriogenology 35: 1197-1207 (1991).

13. Colver, R.M., Howe, A.M., McDonough, P.G. and Boldt, J. Influence of growth factors in defined culture medium on in vitro development of mouse embryos. J. Fert. Steril. 55:194-199 (1991).

14. Carpenter, G. and Cohen, S. Epidermal growth factor. . Ann. Rev. Biochem. 48:193-216 (1979).

15. Gospodarowicz, D. Epidermal and nerve growth factors in mammalian development. Ann. Rev. Physiol. 43:251-263 (1981).

16. Schlessinger, J. Allosteric regulation of the epidermal growth factor kinase. J. Cell Biol. 103:2067-2072 (1987).

17. Fisher, D.A. Hormone epidermal growth factor interactions in development. Hormone Res. 33:69-75 (1990).

18. Paria, B.C., Tsukamura, H. and Dey, S.K. Epidermal growth factor-specific protein tyrosine phosphorylation in preimplantation embryo development. Biol. Reprod. 45: $711-718$ (1991).

19. Paria, B.C., Tsukamura, H. and Dey, S.K. Preimplantation embryo development requires epidermal growth factor (EGF)-specific protein tyrosine phosphorylation. Biol. Reprod. 44 (Suppl. 1):96 abstr. (1991).

20. Sanbuissho, A., Coskin, S. and Lin, Y.C. Stimulatory action of epidermal growth factor (EGF) on bovine oocyte maturation in serum free defined medium.

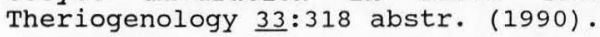

21. Rose, T.A., Fischer, B. and Sheffield, L.G. Role of EGF in oocyte-somatic cell interactions in the bovine follicle. Biol. Reprod. 44 (Suppl. 1):148 abstr. (1991).

22. Lorenzo, P., Illera, M.J., Sanchez, J., Silvan, G. and Illera, J.C. The effect of EGF on cumulus expansion and bovine oocyte maturation in vitro. Theriogenology 37: 250 abstr. (1992). 
23. Coskin, S., Sanbuissho, A., Lin, Y.C. and Rikhisa, Y. Ferilizability and subsequent developmental ability of bovine oocytes matured in medium containing epidermal growth factor (EGF). Theriogenology 36:485-494 (1991).

24. Skinner, M.K., Lobb, D. and Dorrington, J.H. Ovarian thecal/interstitial cells produce an epidermal growth factor-like substance. Endocrinology 121:1892-1899 (1987).

25. Hsu, C.J., Holmes, S.D. and Hammond, J.M. Ovarian epidermal growth factor activity, concentration in porcine follicular fluid during follicular enlargement. Biochem. Biophys. Res. Comm. 147:242-247 (1987).

26. Paria, B.C. and Dey, S.K. Preimplantation embryo development in vitro: cooperative interactions among embryos and role of growth factors. Proc. Natl. Acad. Sci. $87: 4756-4760$ (1990).

27. Schultz, R.M. and Dardik, A. Stimulatory effect of TGF- $\alpha$ /EGF on the rate of mouse blastocoel expansion. Biol. Reprod. 44 (Suppl. 1):88 abstr. (1991).

28. Galway, A.B., Oikawa, M., Ny, T. and Hsueh, A.J.W. Epidermal growth factor stimulates tissue plasminogen activator activity and messenger ribonucleic acid levels in cultured rat granulosa cells: mediation by pathways independent of protein kinases $-A$ and $-C$. Endocrinology 125:126-135 (1989).

29. Keefer, C.L. Development of in vitro produced bovine embryos cultured individually in a simple medium: effects of EGF and TGF-BI. Theriogenology 37:236 abstr. (1992) .

30. Rappolee, D.A., Sturm, K.S., Schultz, G.A., Pedersen, R.A. and Werb, $Z$. The expression of growth factor ligands and receptors in preimplantation mouse embryos. In: Heyner, S., Wiley, L.M. (eds.), Early Embryo Development and Paracrine Relationships. Alan R. Liss, New York, 1990, pp. 11-25.

31. Corps, A.N., Brigstock, D.R., Littlewood, C.J. and Brown, K.D. Receptors for epidermal growth factor and insulin-like growth factor-I on preimplantation trophoderm of the pig. Development 110:221-227 (1990).

32. Huet-Hudson, Y.M., Chakraborty, C., De, S.K., Suzuki, Y., Andrews, G.K. and Dey, S.K. Estrogen regulates synthesis of EGF in mouse uterine epithelial cells. Mole. Endocrinology 4 :510-523 (1990). 
33. Mukku, V.R. and Stancel, G.L. Regulation of epidermal growth factor receptors by estrogen. J. Biol. Chem. 260: $9820-9824$ (1985).

34. Zhang, Z., Krause, M. and Davis, D.L. The epidermal growth factor (EGF) receptor and EGF-stimulated prostaglandin (PG) secretion in the pig. J. Anim. Sci. 69 (Suppl. 1):410 abstr. (1991).

35. Brown, M.J., Zogg, J.L., Schultz, G.S. and Hilton, F.K. Increased binding of epidermal growth factor at the implantation sites in mouse uteri. Endocrinology $\underline{12}$ : 2882-2888 (1989).

36. Nielsen, L.L., Werb, Z. and Pedersen, R.A. Induction of c-fos transcripts in early postimplantation mouse embryos by TGF- $\alpha$, EGF, PDGF, and FGF. Mole. Reprod. Develop. 29:227-237 (1991).

37. Derynck, R. Transforming growth factor- $\alpha$ : structure and biological activities. J. Cell. Biachem. 32:293-304 (1986).

38. Larson, R.C., Ignotz, G.G. and Currie, W.B. Platelet derived growth factor (PDGF) initiates completion of the fourth cell cycle of bovine embryo development. J. Reprod. Fert. Abstract Series $\underline{7}: 6$ (1991)

39. Dore, J.J.E., Gao, K., Bouley, D.M., Wilkinson, J.E. and Godkin, J.D. Immunohistochemical localization of $\mathrm{TGF}-\alpha$ and TGF- $\beta 1$ in bovine uterine endometrium. Biol. Reprod. 44 (Suppl. 1):97 abstr. (1991).

40. Schreiber, A.B., Winkler, M.E. and Derynck, R.

Transforming growth factor $-\alpha$. A more potent angiogenic mediator than epidermal growth factor. Science 232:1250 (1986).

41. Williams, M.F. The vascular architecture of the rat uterus influenced by estrogen and progesterone. Am. J. Anat. $83: 247-307$ (1948).

42. Assoian, R.K., Komoriya, A., Meyers, C.A. and sporn, M.B. Platelet derived transforming growth factor $B$. J. Biol. Chem. 42:428 abstr. (1983).

43. Mclaren, A. and Smith, R. Functional test of tight junctions in the mouse blastocyst. Nature 267:351-353 (1977). 
44. Roberts, A.B., Sporn, M.B., Assoian, R.K., Smith, J.M., Roche, N.S., Wakefield, L.M., Heine, U.I., Liotta, L.A., Falanga, V., Kehrl, J.H. and Fauci, A.S. Transforming growth factor type B: rapid induction of fibrosis and angiogenesis in vivo and stimulation of collagen formation in vivo. Proc. Natl. Acad. Sci. 83: 4167-4171 (1986).

45. Zubay, G.L. Biochemistry. Addison-Wesley, Menlo Park, California, 1983, p. 1135.

46. Williams, J.E. and Butler, J.E. Expression of insulinlike growth factor-I (IGF-I) gene by ovine oviductal cells. J. Anim. Sci. 69 (Suppl. 1):406 abstr. (1991).

47. Simmen, R.C.M., Simmen, F.A., Hofig, A., Farmer, S.J. and Bazer, F.W. Hormonal regulation of insulin-like growth factor gene expression in pig uterus. Endocrinology 127:2166-2174 (1990).

48. Mattson, B.A., Rosenblum, I.Y., Smith,. R.M. and Heyner, S. Autoradiographic evidence for insulin and insulinlike growth factor binding to early mouse embryos. Diabetes 37:585-589 (1988).

49. Heyner, S., Rao, L.V., Jarett, L. and Smith, R.M. preimplantation mouse embryos internalize maternal insulin via receptor-mediated endocytosis: pattern of uptake and functional correlation. Develop. Biol. 134: $48-58$ (1989).

50. Harvey, M.B. and Kaye, P.L. Mouse blastocysts respond metabolicaliy to short-term stimulation by insulin and IGF-I through the insulin receptor. Mole. Reprod. Develop. 29:253-258 (1991).

51. Lee, J.E., Pintar, J. and Efstratiadis, A. Pattern of the insulin-like growth factor II gene expression during early mouse embryogenesis. Development 110:151159 (1990).

52. Mummery, C.L. and van den Eijnden-van Raaij, A.J.M. Growth factors and their receptors in differentiation and early murine development. Cell. Diff. Develop. 30: $1-18(1990)$.

53. Gandolfi, F., Brevini, T.A.L., Modina, S. and Lauria, A. Detection and characterization of a growth factor in bovine oviduct secretions. J. Reprod. Fert. Abstract Series 7:6 (1991). 
54. Holmes, P.V., Svalander, P.C. and Olovsson, M. PDGF in human and mouse blastocyst medium and serum, and in paired samples of human follicle fluid and serum from natural IVF-cycles. Biol. Reprod. 44 (Suppl. 1):159 abstr. (1991).

55. Uhlrich, S., Tiollier, J., Tardy, M. and Taylot, J.L. Biochemical and biological characterization of bFGF extracted from human placenta. In: Cedard, L., Alsat, E., Challier, J.-C., Chaouat, G. and Malassine, A. (eds.), Placental Communications: Biochemical, Morphological and Cellular Aspects. vol. 199:112 abstr. (1990).

56. Rajput-Williams, J., Jones, D.S.C., Schofield, J.P., Lindsay, $M$. and Smith, S.K. Demonstration of expression of acidic and basic fibroblast growth factors in human endometrium. J. Reprod. Fert. Abstract Series 7: 41 (1991).

57. Liesi, P., Rechardt, L. and Wartiovaara, J. Nerve growth factor induces adrenergic neuronal differentiation in F9 teratocarcinoma cells. Nature 306:265-267 (1983).

58. Barnett, D.K. and Bavister, B.D. Development of in vitro fertilized hamster embryos to morulae and blastocysts in a chemically defined culture medium. Biol. Reprod. 44 (Suppl. 1):155 abstr. (1991).

59. Bavister, B.D., Leibfried, M.L. and Lieberman, G. Development of preimplantation embryos of the golden hamster in a defined culture medium. Biol. Reprod. $\underline{28}: 235-247$ (1983).

60. Kane, M.T. and Bavister, B.D. Protein-free culture medium containing polyvinylalcohol, vitamins, and amino acids supports development of eight-cell hamster embryos to hatching blastocysts. J. Exp. Zool. 247:183187 (1988).

61. Carney, E.W. and Foote, R.H. Improved development of rabbit one-cell embryos to the hatching blastocyst stage by culture in a defined, protein-free culture medium. J. Reprod. Fert. 91:113-123 (1991).

62. Pinyopummintr, T. and Bavister, B.D. In vitro-matured/ in vitro-fertilized bovine oocytes can develop into morulae/blastocysts in chemically defined, proteinfree media. Biol. Reprod. $45: 736-742$ (1991). 
63. Saeki, K., Hoshi, M., Leibfried-Rutledge, M.L. and First, N.L. In vitro fertilization and development of bovine oocytes matured in serum-free medium. Biol. Reprod. 44:256-260 (1991).

64. Seidel, G.E., Glass, T. and Olson, S.E. Culture of 1cell bovine embryos to blastocysts in chemically defined media. Biol. Reprod. 44 (Suppl. 1): 155 abstr. (1991).

65. Parrish, J.J., Susko-Parrish, J., Winer, M.A. and First, N.L. Capacitation of bovine sperm by heparin. Biol. Reprod. 38:1171-1180 (1988).

66. Zhang, L., Flood, M.R., Bunch, T.D., Hansel, W. and Godke, R.A. Evaluating bovine oviduct cells used in combination with bovine cumulus cells to co-culture IVF-derived bovine embryos in vitro. Proc. Int. Cong. Anim. Reprod. Artif. Insem. In Press abstr. (1992).

67. Yang, Z. and Seidel, G.E., Jr. Development of bovine embryos in chemically defined medium at different levels of polyvinyl alcohol. Theriogenology 37:328 abstr. (1992). 
APPENDIXES 
Appendix I. Formulation of Fert-TALP

$\begin{array}{ll}\text { Ingredient } & \text { Amount per } \\ & 0.666 \mathrm{~g} \\ \mathrm{KCl} & 0.023 \mathrm{~g} \\ \mathrm{NaH}_{2} \mathrm{PO}_{4} & 0.0036 \mathrm{~g} \\ \mathrm{Na} \mathrm{Lactate*} & 0.09 \mathrm{ml} \\ \mathrm{MgCl}_{2}\left(7 \mathrm{H}_{2} \mathrm{O}\right) & 0.011 \mathrm{~g} \\ \mathrm{NaHCO}_{3} & 0.21 \mathrm{~g} \\ \mathrm{CaCl}_{2}\left(2 \mathrm{H}_{2} \mathrm{O}\right) & 0.0294 \mathrm{~g} \\ \mathrm{Na} \mathrm{Pyruvate} & 0.0022 \mathrm{~g} \\ \mathrm{PHE} \text { stock** } & 1.00 \mathrm{ml} \\ \mathrm{Glucose} & 0.09 \mathrm{~g} \\ \mathrm{BSA} \text { (Fraction V) } & 0.6 \mathrm{~g} \\ \text { Gentamicin Sulfate } & 0.25 \mathrm{mg} \\ \text { Caffeine } & 0.0971 \mathrm{~g}\end{array}$

After dissolved, filter through 0.2 micron filter

and store at $4^{\circ} \mathrm{C}$ for up to 4 weeks. Equilibrate with $5 \% \mathrm{CO}_{2}$ and warm to $39^{\circ} \mathrm{C}$ before using.

* $60 \%$ Sodium lactate syrup

**PHE stock: $\begin{array}{ll}\text { penicillamine } 0.0186 \mathrm{~g} \\ \text { hypotaurine }\end{array}$

epinephrine $0.0009 \mathrm{~g}$

Appendix II. Formulation for Sp-TALP

Ingredient Amount per $100 \mathrm{ml}$

$\mathrm{NaCl}$

$0.5845 \mathrm{~g}$

$\mathrm{KCl}$

$0.0231 \mathrm{~g}$

$\mathrm{NaHCO}_{3}$

$0.21 \mathrm{~g}$

$\mathrm{NaH}_{2} \mathrm{PO}_{4}$

$0.0041 \mathrm{~g}$

Na Lactate*

$0.19 \mathrm{ml}$

$\mathrm{CaCl}_{2}\left(2 \mathrm{H}_{2} \mathrm{O}\right)$

$\mathrm{MgCl}_{2}\left(7 \mathrm{H}_{2} \mathrm{O}\right)$

$0.0294 \mathrm{~g}$

$0.0081 \mathrm{~g}$

HEPES (Sigma H3375) $0.2383 \mathrm{~g}$

Na Pyruvate

$0.011 \mathrm{~g}$

BSA (Fraction V)

$0.6 \mathrm{~g}$

Gentamicin Sulfate $6.25 \mathrm{ug}$

Heparin

500 units

Store and filter as described for Fert-TALP.

* $60 \%$ Sodium lactate syrup 
Appendix III. Formulation for Control Medium

Directions for making chemically defined medium (CDM), which was first described by George seidel at colorado state.

First, make CDM stock solution $(270 \mathrm{ml})$, to be stored up to 2 months at $4^{\circ} \mathrm{C}$. This should be made up the night before so that the PVA has time to go into solution. To $200 \mathrm{ml}$ of deionized water, add the following:

\section{Ingredient}

$\mathrm{NaCl}$

$\mathrm{NaH}_{2} \mathrm{CO}_{3}$

Glycine

KCl

Glucose

$\mathrm{CaCl}_{2}\left(2 \mathrm{H}_{2} \mathrm{O}\right)$

$\mathrm{MgCl}_{2}\left(7 \mathrm{H}_{2} \mathrm{O}\right)$

Polyvinyl alcohol

$\mathrm{Na}$ Lactate*

Insulin**

Gentamicin Sulfate***

MEM Nonessential Amino

Acid Solution (100X)

MEM Essential Amino

Acid Solution (50X)

\section{Amount}

$$
\begin{aligned}
& 1.4913 \mathrm{~g} \\
& 0.6300 \mathrm{~g} \\
& 0.1104 \mathrm{~g} \\
& 0.1731 \mathrm{~g} \\
& 0.1080 \mathrm{~g} \\
& 0.0882 \mathrm{~g} \\
& 0.306 \mathrm{~g} \\
& 0.300 \mathrm{~g} \\
& 0.219 \mathrm{~g} \\
& 0.150 \mathrm{ml} \\
& 0.750 \mathrm{ml} \\
& 3.000 \mathrm{ml} \\
& 6.000 \mathrm{ml}
\end{aligned}
$$

Add deionized water to $270 \mathrm{ml}$ and pass through 0.2 micron filter prior to storage.

* $60 \%$ Sodium lactate syrup

** Insulin $10 \mathrm{mg} / \mathrm{ml}$ stock solution at $24 \mathrm{IU} / \mathrm{mg}$.

***From $10 \mathrm{mg} / \mathrm{ml}$ stocks solution buffered to $\mathrm{pH} 7.4$ in PBS

To make CDM Final (10 ml), dissolve $0.0055 \mathrm{~g}$ Na pyruvate and $0.0146 \mathrm{~g}$ glutamine into $10 \mathrm{ml}$ deionized water. Then add $1 \mathrm{ml}$ of this to $9 \mathrm{ml}$ of $\mathrm{CDM}$ stock $=10 \mathrm{ml} \mathrm{CDM}$ Final. Equilibrate in a $5 \% \mathrm{CO}_{2}$ incubator for at least 2 hours. Then adjust $\mathrm{pH}$ to 7.4 with $1 \mathrm{M} \mathrm{HCl}$. The Final $\mathrm{CDM}$ should be filtered (discard the first $1 \mathrm{ml}$ ) with a 0.2 micron filter and used with 10 days when stored at $4{ }^{\circ} \mathrm{C}$. Culture embryos in $5 \% \mathrm{CO}_{2}, 5 \% \mathrm{O}_{2}, 90 \% \mathrm{~N}_{2}$ atmosphere. 


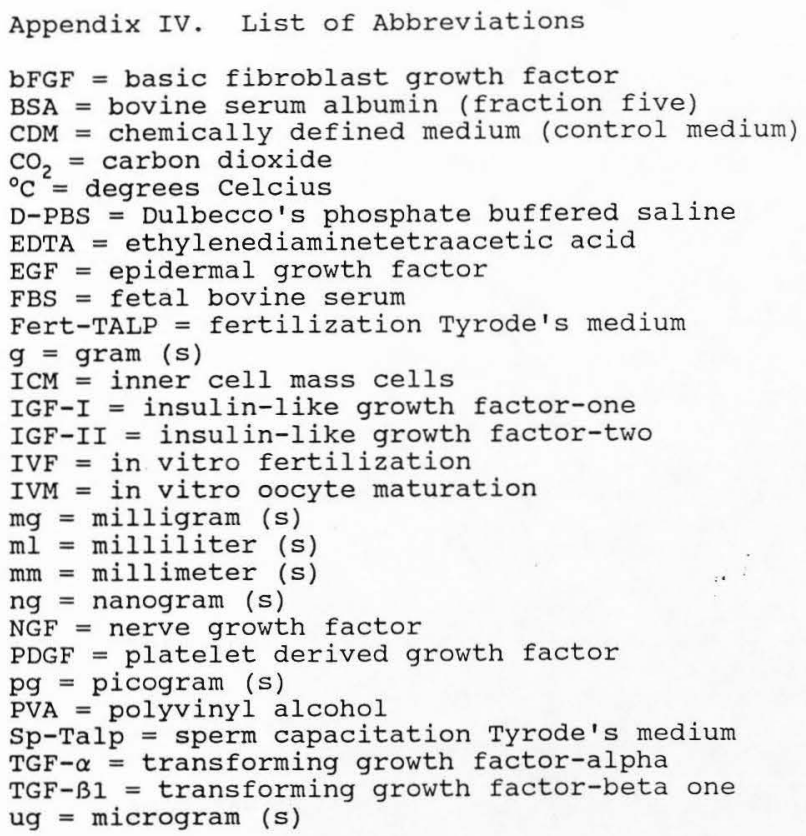


CURRICULUM VITAE

Mark Randall Flood

Date of Birth: April 14, 1963

Academic Background:

B.S., 1985, Purdue University, Animal Science (Reproductive Physiology)

M.S., 1987, Washington State University, Animal Science (Embryo Physiology)

Ph.D.,1992, Utah State University, Animal Science (Embryo Physiology)

Work Experience:

1982-1985 Veterinary Assistant, Dr.. M. Moore, Rising Sun, IN, and Dr. I. Rimstidt, Madison, IN

1985-1986 Lab Assistant, Animal Science Department Washington State University

1986-1987 Teaching Assistant, Statistics Department Washington State University

1987-1991 Research Assistant, Animal, Dairy and Vet Sciences Department, Utah State University

1991-1992 Embryo Consultant, HyClone Labs, Logan, Utah

\section{Teaching Experience:}

Spring 1986 Teaching Assistant in Artificial Insemination and Pregnancy Detection course at Washington state University

1986-1987 Teaching Assistant in undergraduate and graduate level statistics courses at Washington state University

Winter 1989 Teaching Assistant in beginning undergraduate Animal science course at Utah State University

Spring 1990 Teaching Assistant in Animal Cytogenetics course at Utah state University 


\title{
Computer Experience:
}

- SAS and SPSS statistical packages

- Wordperfect and Symphony word processing programs

- Harvard Graphics program

\section{Research Experience:}

Embryo Research

- porcine, bovine, ovine and murine embryos

- oocyte and embryo collection, in vitro fertilization, and in vitro embryo culture

- embryo manpulations and metabolism

- embryo freezing and thawing.

- embryo fibroblast cell culture

- publication preparation and professional presentations

\section{Molecular Biology Research}

\author{
DNA manipulations \\ DNA extraction from blood and tissue \\ DNA extraction from embryo cells \\ gel electrophoresis \\ restriction enzyme digestions \\ Southern blot and probe hybridization \\ genomic DNA library preparation \\ library screening and subcloning \\ large scale plasmid preparations \\ DNA amplification by PCR techniques \\ DNA sequencing \\ Autoradiography and photography
}

\section{Honors:}

Received first place in graduate student paper competition at the annual meeting of the American society of Animal Science, held in Logan, Utah in 1987. The presentation was based on my M.S. thesis research. 
Professional organizations:

International Embryo Transfer Society (IETS)

American Society of Animal Science (ASAS)

\section{Publications:}

Flood, M.R. and Wiebold, J.L. 1988. Glucose metabolism by preimplantation pig embryos. J. Reprod. Fert. $84: 7-12$.

Selgrath, J.P., Flood, M.R., and Wright, R.W., Jr. 1989. Glucose utilization by enzymatically-formed

trophoblastic vesicles and day-14 porcine blastocysts. Theriogenology 32:37-43.

Flood, M.R., Kern, D., Spendlove, R., and Bunch, T.D. 1992. Fetalclone versus fetal bovine serum for in vitro maturation, fertilization and culture. Theriogenology 37:212 (abstract).

Manuscripts accepted for publication:

Zhang, L., Flood, M.R., Bunch, T.D., Hansel, W., and Godke, R.A. Evaluating bovine oviduct cells used in combination with bovine cumulus cells to co-culture IVF-derived embryos in vitro. International congress of Anim. Reprod. and A.I., Aug., 1992

Morrey, J.D., Bourn, S., Sidwell, R.W., Sisson, D.V., Bunch, T.D., and Flood, M.R. 1991. Two-cell blockage of FVB/N mouse embryo development: An artifact of cell culture. Encyclia.

Manuscripts in Preparation:

Flood, M.R., Gage, T.L. and Bunch, T.D. Effect of various growth-promoting factors on preimplantation bovine embryo development in vitro. 